\title{
EBF1/PDGFRB Fusion Protein
}

National Cancer Institute

\section{Source}

National Cancer Institute. EBF1/PD GFRB Fusion Protein. NCI Thesaurus. Code C128924.

A fusion protein encoded by the EBF1/PDGFRB fusion gene. This protein is comprised of the first 600 amino acids of transcription factor COE1, including the DNA binding domain, fused to the C-terminal transmembrane and cytoplasmic domains of the platelet-derived growth factor receptor beta protein, including the protein kinase domain. 